\title{
Pigmented contact dermatitis development in a Sjögren's syndrome patient
}

\section{Barwnikowe kontaktowe zapalenie skóry u pacjentki z zespołem Sjögrena}

\author{
Koray Durmaz', Arzu Ataseven', Ilkay Ozer', Fahriye Kilinc² \\ 'Department of Dermatology, Faculty of Medicine, Necmettin Erbakan University Meram, Konya, Turkey \\ ${ }^{2}$ Department of Pathology, Faculty of Medicine, Necmettin Erbakan University Meram, Konya, Turkey \\ 'Katedra Dermatologii, Wydział Lekarski, Necmettin Erbakan University Meram, Konya, Turcja \\ ${ }^{2}$ Katedra Patologii, Wydział Lekarski, Necmettin Erbakan University Meram, Konya, Turcja
}

Dermatol Rev/Przegl Dermatol 2021, 108, 31 |-313

DOI: https://doi.org/l0.51/4/dr.2021.1 10741

Pigmented contact dermatitis (PCD) is characterized by facial hyperpigmentation and has been associated with allergens that are often found in cosmetics [1]. Sjögren's syndrome (SJS) is an autoimmune exocrinopathy present with lymphocytic infiltration of the lachrymal and salivary glands [2]. Herein, we present a case of facial melanosis with negative patch test and photo patch test reactions to the cosmetics and standard thin layer rapid use epicutaneous (TRUE) test allergens. She has also been diagnosed with SJS.

A 50-year-old female patient with SJS Fitzpatrick skin type 3 was admitted to our clinic because of 8 -year history of intense hyperpigmentation of the face (fig. 1) and both hands (fig. 2). When the patient was referred to us, she was using systemic methylprednisolone, hydroxychloroquine, azathioprine and an unknown cream for moisturizing topically for a long time. Intense hyperpigmentation on the bilateral malar region and dorsum of the hands was observed in the dermatological examination. Antinuclear antibody (ANA) yielded positive results with $1 / 160$ titre in the serologic tests. Anti-SSA (anti-Ro), anti-SSB (anti-La) were also positive however, antidsDNA, anti-Sm, rheumatoid factor (RF), anti-centromere antibodies, anti-Scl70 and anti-CCP antibodies were negative. Dermoscopy of facial hyperpigmentation showed the pseudo network, grey dots/granules and telangiectatic vessels. Patch test and photo patch test reactions to the cosmetics and standard TRUE test. No allergic reaction was detected in the relevant allergens. Histopathological examination showed interface dermatitis with vacuolar basal degeneration, lymphocytic infiltration, melanophages and colloid bodies in the superficial dermis (fig. 3). Direct immunofluorescence study was also performed at the perilesional site on the left cheek. It was negative. Clinical and histopathological features were consistent with the PCD eruption. In addition to an SPF50/
Barwnikowe kontaktowe zapalenie skóry (pigmented contact dermatitis - PCD) charakteryzuje się występowaniem przebarwień na skórze twarzy. W piśmiennictwie wskazuje się na związek schorzenia z alergenami często znajdującymi się w produktach kosmetycznych [1]. Zespół Sjögrena (Sjögren's syndrome - SJS) jest egzokrynopatią o podłożu autoimmunologicznym, w której dochodzi do powstawania nacieków zapalnych z limfocytów w śliniankach oraz gruczołach łzowych [2]. W pracy przedstawiamy przypadek pacjentki z melanozą skóry twarzy, u której testy płatkowe i próby świetlne wykrywające reakcje alergiczne na substancje zawarte w kosmetykach, a także standardowy szybki naskórkowy test alergologiczny (thin layer rapid use epicutaneous - TRUE) dały wynik ujemny. U pacjentki rozpoznano SJS.

Kobieta 50-letnia z rozpoznaniem SJS o fototypie skóry 3 według klasyfikacji Fitzpatricka została przyjęta do naszej kliniki z powodu utrzymujących się od 8 lat nasilonych przebarwień umiejscowionych na skórze twarzy (ryc. 1) i obu rąk (ryc. 2). W chwili zgłoszenia się do naszej kliniki pacjentka przez długi czas stosowała leczenie ogólne metyloprednizolonem, hydroksychlorochiną, azatiopryną oraz nieznanym kremem o działaniu nawilżającym. W badaniu dermatologicznym stwierdzono nasilone przebarwienia umiejscowione obustronnie na skórze policzków i na grzbietowej powierzchni rąk. Badanie w kierunku przeciwciał przeciwjądrowych (ANA) dało wynik dodatni $\mathrm{z}$ mianem $1 / 160$. W badaniu w kierunku przeciwciał anty-SSA (Ro) i anty-SSB (La) także uzyskano wynik dodatni. Oznaczenia przeciwciał przeciw dsDNA, Sm i czynnikowi reumatoidalnemu, a także przeciwciał antycentromerowych, anty-Scl70 i anty-CCP były ujemne. Badanie dermoskopowe przebarwień umiejscowionych na twarzy wykazało obecność pseudosieci, szarych kropek lub ziaren oraz teleangiektazji. U pacjentki wykonano test i fototest płatkowy w celu potwierdzenia lub wykluczenia reakcji alergicznych na substancje znajdujące się w kosmetykach oraz standardowy test alergenowy, test płatkowy TRUE. Nie potwierdzono reakcji alergicz- 


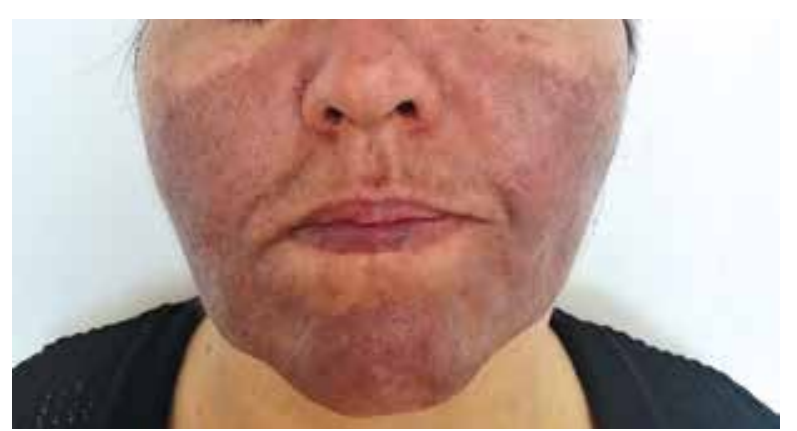

Figure I. Hyperpigmentation on the mid and I/3 bottom of the face

Rycina I. Przebarwienia w środkowej i dolnej trzeciej części twarzy

PPD39 sunscreen, we prescribed tacrolimus $0.1 \%$ ointment and azelaic acid 20\% cream for 2 months. A little improvement of intense hyperpigmentation was detected. The patient is being followed up.

SJS patients show signs of dryness involving organs, particularly of the skin (xeroderma), eyes (xerophthalmia) and mouth (xerophthalmia). These symptoms are related to an immune-mediated process, lymphocyte infiltration and gradual destruction of the involved exocrine glands [3].

PCD is a lichenoid tissue reaction that causes pigment incontinence and is characterized by reticular grey-brownish pigmentation in sun-exposed areas, particularly on the face. In the literature, co-development of PCD and SJS have been reported. It was pointed out that PCD may be a cutaneous manifestation of SJS closely related to the anti-SSA (Ro) antibody [1]. The exact etiopathogenesis of PCD is unknown. In the differential diagnosis, allergic contact dermatitis (ACD), lichen planus pigmentosus, friction melanosis, Berloque dermatitis, macular amyloidosis, postinflammatory hyperpigmentation, drug-induced hyperpigmentation, and hyperpigmented cutaneous lupus erythematosus (CLE) can be included.

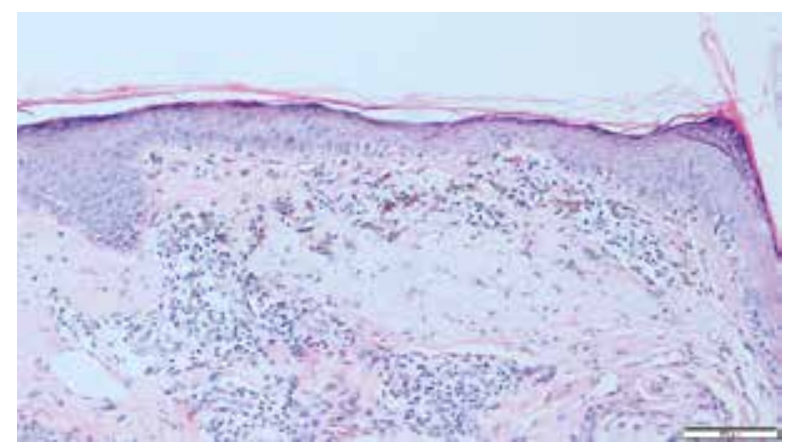

Figure 3. Interface dermatitis with vacuolar basal layer degeneration. Melanophages and perivascular lymphocytes are seen in the dermis $(\mathrm{H}+\mathrm{E}, 100 \times)$

Rycina 3. Interface dermatitis ze zwyrodnieniem wodniczkowym komórek warstwy podstawnej. W skórze właściwej widoczne są melanofagi i limfocyty okołonaczyniowe (barwienie $\mathrm{H}+\mathrm{E}, 100 \times$ )

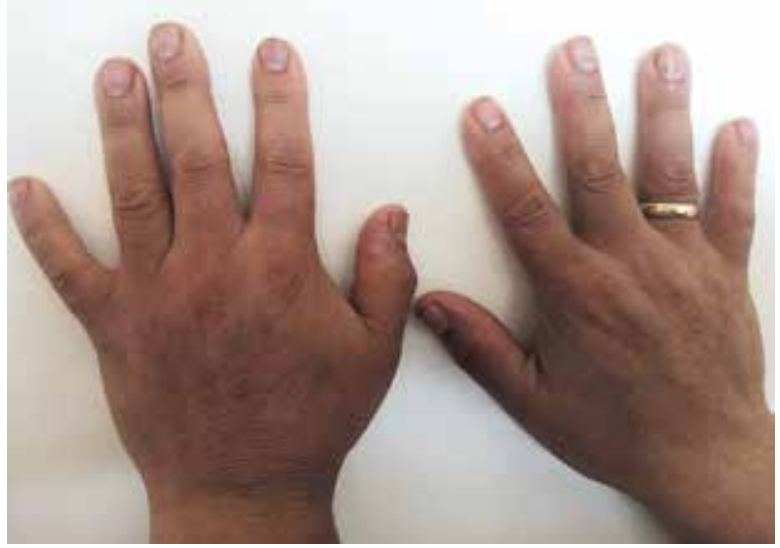

Figure 2. Hyperpigmentation on the dorsum of both hands Rycina 2. Przebarwienia na powierzchni grzbietowej obu rąk

nych na badane alergeny. $W$ badaniu histopatologicznym stwierdzono interface dermatitis ze zwyrodnieniem wodniczkowym komórek warstwy podstawnej, naciek limfocytarny oraz obecność melanofagów i ciałek hialinowych w powierzchownej warstwie skóry właściwej (ryc. 3). Wynik badania skóry w otoczeniu zmian metodą bezpośredniej immunofluorescencji był negatywny. Obraz kliniczny i histopatologiczny odpowiadał zmianom w przebiegu PCD. Pacjentce zalecono, oprócz hipoalergicznego kremu z filtrem przeciwsłonecznym SPF50/PPD39, 0,1\% takrolimus w maści oraz kwas azelainowy do stosowania przez 2 miesiące. Stwierdzono nieznaczną poprawę stanu skóry. Pacjentka jest pod obserwacją.

W przebiegu SJS u pacjentów występują nacieki zapalne w obrębie nabłonka gruczołów zewnątrzwydzielniczych. U osób z SJS stwierdza się objawy suchości skóry (kseroderma), oczu (kseroftalmia) i jamy ustnej (kserostomia). Objawy te są związane z toczącym się procesem o podłożu immunologicznym, naciekaniem limfocytów oraz stopniowym niszczeniem zajętych gruczołów zewnątrzwydzielniczych [3].

PCD jest reakcją lichenoidalną, która powoduje nietrzymanie pigmentu i cechuje się obecnością siateczkowatych, szarobrązowych zmian barwnikowych w miejscach eksponowanych na UV, szczególnie na twarzy. Współistnienie PCD i SJS było opisywane w piśmiennictwie. Wskazywano, że PCD może być objawem skórnym SJS ściśle związanym z aktywnością przeciwciał anty-SSA (Ro) [1]. Etiopatogeneza PCD nie jest dokładnie poznana. W diagnostyce różnicowej można uwzględnić następujące jednostki chorobowe: alergiczne kontaktowe zapalenie skóry, liszaj płaski barwnikowy, melanozę wywołaną tarciem, fotokontaktowe zapalenie skóry typu berloque, amyloidozę plamkowata, przebarwienia pozapalne, przebarwienia polekowe oraz toczeń rumieniowaty skórny z przebarwieniami.

Przebarwienia skóry mogą być również spowodowane hydroksychlorochiną, która może wywoływać czarne 
Hyperpigmentation can also be induced by certain drugs such as hydroxychloroquine, an antimalarial drug, which can cause black, blue-grey hyperpigmentation of the skin, nails, and mucous membranes. After the hydroxychloroquine is withdrawn, the hyperpigmentation gradually disappears within 2-6 months [4]. We made a diagnosis of PCD accompanying SJS in our patient, excluding other diagnoses by assessment of clinical, laboratory and histopathological findings.

\section{CONFLICT OF INTEREST}

The authors declare no conflict of interest. lub niebiesko-szare przebarwienia skóry, paznokci i błon śluzowych. Po odstawieniu leczenia przebarwienia stopniowo ustępują w czasie 2-6 miesięcy [4]. Po wykluczeniu innych schorzeń na podstawie oceny klinicznej, laboratoryjnej i histopatologicznej u pacjentki postawiliśmy diagnozę PCD w przebiegu SJS.

\section{KONFLIKT INTERESÓW}

Autorzy nie zgłaszają konfliktu interesów.

\section{References}

\section{Piśmiennictwo}

1. Takeo N., Sakai T., Saito-Shono T., Ishikawa K., Hatano Y., Katagiri K., et al.: Three cases of pigmented cosmetic dermatitis-like eruptions associated with primary Sjogren's syndrome or anti-SSA antibody. J Dermatol 2016, 43, 947-950.

2. Ng K.P., Isenberg D.A.: Sjogren's syndrome: diagnosis and therapeutic challenges in the elderly. Drugs Aging 2008, 25, 19-33.

3. Generali E., Costanzo A., Mainetti C., Selmi C.: Cutaneous and mucosal manifestations of Sjogren's syndrome. Clin Rev Allergy Immunol 2017, 53, 357-370.

4. Cohen P.R.: Hydroxychloroquine-associated hyperpigmentation mimicking elder abuse. Dermatol Ther 2013, 3, 203-210.

Received: 23.01 .2020

Accepted: 5.06.2021

Otrzymano: $23.01 .2020 \mathrm{r}$.

Zaakceptowano: $5.06 .2021 \mathrm{r}$. 